\title{
Nucleic acid sensor for M. tuberculosis detection based on surface plasmon resonance $\dagger$
}

\author{
Nirmal Prabhakar, ${ }^{a, b}$ Kavita Arora, ${ }^{a}$ Sunil K. Arya, ${ }^{a}$ Pratima R. Solanki, ${ }^{a}$ M. Iwamoto,,${ }^{c}$ Harpal Singh ${ }^{b}$ and \\ B. D. Malhotra*a
}

Received 15th May 2008, Accepted 23rd June 2008

First published as an Advance Article on the web 5th August 2008

DOI: 10.1039/b808225a

Cysteine modified $\mathrm{NH}_{2}$-end peptide nucleic acid (PNA) (24-mer) probe and 5'-thiol end labeled deoxyribonucleic acid (DNA) probes specific to Mycobacterium tuberculosis have been immobilized onto BK-7 gold coated glass plates for the detection of complementary, one-base mismatch, non-complementary targets and complementary target sequence in genomic DNA of Mycobacterium tuberculosis using a surface plasmon resonance (SPR) technique. The DNA/Au and PNA/Au bio-electrodes have been characterized using contact angle, atomic force microscopy (AFM), electrochemical impedance spectroscopy (EIS) and cyclic voltammetric (CV) techniques, respectively. It is revealed that there is a 252 millidegrees SPR angle change in the case of PNA immobilization and 205 millidegrees for DNA immobilization, indicating increased amount of immobilized PNA molecules. Hybridization studies reveal that there is no binding of the non-complementary target to DNA/Au and PNA/Au electrode. Compared to the DNA/Au bioelectrode, PNA/Au electrode has been found to be more efficient for detection of one-base mismatch sequence. The PNA/Au bioelectrode shows better detection limit $\left(1.0 \mathrm{ng} \mathrm{ml}^{-1}\right)$ over the DNA-Au bioelectrode $\left(3.0 \mathrm{ng} \mathrm{ml}^{-1}\right)$. The values of the association $\left(k_{\mathrm{a}}\right)$ and dissociation rate constant $\left(k_{\mathrm{d}}\right)$ for the complementary sequence in case of the PNA/Au bioelectrode have been estimated as $8.5 \times 10^{4} \mathrm{~m}^{-1} \mathrm{~s}^{-1}$ and $3.6 \times 10^{-3} \mathrm{~s}^{-1}$, respectively.

\section{Introduction}

According to a World Health Organization report in 1997, Mycobacterium tuberculosis, a causative organism for tuberculosis, is the reason for death of nearly 3 million people every year and the registration of nearly 1,000 new cases every hour. Most widely used conventional techniques for detection of $M$. tuberculosis, such as PCR (polymerase chain reaction), RFLP (restriction fragment length polymorphism), immunoassays and southern hybridization, have high sensitivity and specificity but are known for their limitations in terms of labour intensiveness, increased assay time (hours to days) and costly reagents. ${ }^{1}$ And resistance to several drugs during treatment is the main hurdle in its detection via traditional molecular biological methods. There is, therefore, an urgent need for a sensitive, specific, faster and cost-effective method for detection of pathogens/microbes. In this context, biosensors can provide alternative solutions for such requirements, since they allow direct (non-labeled) and

${ }^{a}$ Biomolecular Electronics \& Conducting Polymer Research Group, National Physical Laboratory, Dr KS Krishnan Road, New Delhi, 110012, India.E-mail: bansi.malhotra@gmail.com; Fax: +91 11 45609152; Tel: +91 1145609310

${ }^{b}$ Centre for Biomedical Engineering, Indian Institute of Technology, Hauz Khas, New Delhi, 110016, India

'Department of Physical Electronics, Tokyo Institute of Technology, Tokyo, Japan

$\dagger$ Electronic supplementary information (ESI) available: Electrochemical studies. See DOI: 10.1039/b808225a rapid detection of pathogenic microbes and other organisms. Nowadays, nucleic acid sensors are gaining more attention over traditional diagnostic methods, as they are faster, simpler and cost effective. ${ }^{2-4}$

For the fabrication of a stable and sensitive biosensor, immobilization of a biomolecule onto a desired surface is very crucial. In the nucleic acid based biosensors, immobilization of the nucleic acid probe involves use of a thiolated probe or biotinylated oligonucleotide for its binding over a streptavidin/avidin-modified dextran/carboxymethyl dextran gold film. The total immobilization time in the latter case is about 3 to 5 days, which is much longer than about $3 \mathrm{~h}$ required for thiolated probe immobilization. ${ }^{5-8}$ In the development of DNA based biosensors, self assembled monolayers (SAMs) or ordered structures of thiolated DNA on a gold surface can be achieved via use of spacer molecules between DNA and the thiol moiety, since DNA is known to form a disordered formless globular structure. Moreover, strong electrostatic molecule-molecule and molecule-surface interactions result in reduced bioactivity of poorly ordered DNA. To overcome these problems, uncharged nucleic acid analogues like PNA (peptide nucleic acid) are gaining much attention. PNA mimics DNA due to the presence of a peptide like $N$-(2-aminoethyl) glycine polyamide back bone instead of a sugar-phosphate backbone. Also, SAMs of PNA can efficiently recognize complementary target DNA as per the Watson-Crick rules for base pairing with improved specificity. ${ }^{9-11}$ Besides this, PNA-DNA duplexes are more stable than the corresponding DNA-DNA duplexes. ${ }^{12}$ And PNA, 
being a synthetic biomimetic molecule, is more stable and is less prone to nuclease attack, making the bioelectrode more stable/robust. ${ }^{13}$

In the development of on-line, label-free and selective tools for detection of microbes, DNA and other biomolecules for medical and environmental applications, surface plasmon resonance (SPR) based biosensors are gaining much attention. ${ }^{14,5}$ The SPR method measures refractive index changes that occur upon hybridization, providing a signal that can be directly correlated with the mass density changes on a metal surface. ${ }^{15,16}$ SPR spectroscopy has been used for studying hybridization kinetics of PNA-DNA and PNA-RNA duplexes. The PNA linked to streptavidin at the dextran/gold surface via a biotin linker has been used for in situ hybridization detection of unlabeled DNA targets. ${ }^{17}$ A PNA based SPR biosensor has been developed to study hybridization with complementary $(20-39 \mu \mathrm{M})$ and point mutations at $40{ }^{\circ} \mathrm{C}$ using guanidine thiocyanate concentration 1.5-1.7 M. Further, it has been shown that a perfectly matched PNA allows detection of a single-stranded DNA with the sensitivity of less than $1 \%$ in a background of single-stranded DNA having a single $\mathrm{C}$ to $\mathrm{T}$ point mutation in the region complementary to PNA. ${ }^{18}$

Sato et al. have reported an SPR based biosensor for detection of K-ras mutation using a 15-mer PNA probe that has high affinity for one-base mismatch discrimination at 25 and $40{ }^{\circ} \mathrm{C} .{ }^{19}$ An optical biosensor using localized surface plasmon resonance (LSPR) based on a gold-capped nanoparticle layer immobilized with peptide nucleic acid (PNA) has been designed to recognize target DNA related to tumor necrosis factor in complementary oligonucleotides and PCR-amplified real samples with detection limit of $0.677 \mathrm{pM}$ within 10 minutes. ${ }^{20}$ Tawa et al. have reported use of surface plasmon fluorescence spectroscopy (SPFS) for monitoring DNA hybridization. ${ }^{21}$ Yao et al. have reported the effect of ionic strength on hybridization behavior of PNA with PCR amplicons, revealing that the maximum hybridization signal can be achieved at an intermediate sodium concentration $(\sim 100 \mathrm{mM}){ }^{22}$ Further, these authors have used a surface plasmon field-enhanced fluorescence spectroscopy technique for PCR product analysis. They have used PNA and DNA probes attached to a streptavidin-modified gold surface for realtime monitoring of hybridization with trace amounts of PCR products. The PNA and DNA probe surfaces show detection limits of $100 \mathrm{fmol}$ and $500 \mathrm{fmol}$ of PCR amplicons, respectively, within 1 minute. ${ }^{23}$ Knoll et al. have reported an SPFS based PNA sensor for the detection of long PCR products of genetically modified soybean species, the Round-up Ready_GMO from Monsanto. A detailed quantitative evaluation of the kinetics and affinities of the association and dissociation reactions between the catcher oligonucleotide strands and chromophore-labeled PCR (125 bp) strands from solution have been discussed. ${ }^{24}$

We report studies relating to nucleic acid hybridization using DNA/Au and PNA/Au bioelectrodes to detect the presence of a complementary sequence specific to $M$. tuberculosis, onebase mismatch and non-complementary targets using SPR technique. Attempts have also been made to detect presence of a complementary target in genomic DNA of M. tuberculosis.

\subsection{Materials and methods}

\subsection{Chemicals and reagents}

Cysteine modified PNA (24-mer) sequences specific to $M$. tuberculosis were procured from Panagene, Korea. The thiol modified sequence (24-mer), complementary target DNA sequence, onebase mismatch sequence, non-complementary sequence, Tris buffer, EDTA, potassium monohydrogen phosphate and potassium dihydrogen phosphate were procured from Sigma-Aldrich, USA. $50 \mathrm{~nm}$ gold-coated BK-7 glass plates (24 millimetre diameter) were procured from Autolab, Netherlands. All chemicals used were of molecular biology (MB) grade and all reagents were prepared in de-ionized water from Milli Q 10 TS (resistance 18.2 M $\Omega$ ). All glasswares and solutions were autoclaved prior to being used. PNA and oligonucleotide sequences used for hybridization detection are shown in Table 1.

\subsection{Immobilization of thiolated DNA and PNA onto gold plate}

Prior to immobilization of thiolated DNA and PNA, gold plates were treated with piranha solution $\left(7 \mathrm{H}_{2} \mathrm{SO}_{4}: 3 \mathrm{H}_{2} \mathrm{O}_{2}\right)$ followed by rinsing using de-ionized water and subsequent ultrasonication in absolute ethanol (for about $2 \mathrm{~min}$ ) along with consecutive rinsing with de-ionized water. The 5 '-thiol end DNA and PNA solutions $(100 \mu \mathrm{M})$ prepared in autoclaved de-ionized water were immobilized onto the pre-cleaned gold surface for $8500 \mathrm{~s}$ at $25^{\circ} \mathrm{C}$ and the binding of these molecules (DNA and PNA) was monitored using the SPR technique. The uncovered gold surface was then subsequently blocked by incubating the desired gold surface in $\mathrm{MCH}$ (6-mercapto-1-hexanol) solution for $2 \mathrm{~h}$ to avoid any non-specific binding. It should be noted that we have selected the $\mathrm{MCH}$ molecule as it has the same length of C-chain as the thiol modified DNA/PNA at the 5 ' end, which prevents hindrance due to the spacer molecule in the hybridization process. Besides this, $\mathrm{MCH}$ is known to bring the bound DNA into a more favorable orientation for hybridization. ${ }^{25-27}$ The DNA/PNA immobilized bioelectrode (PNA/Au and DNA/Au) thus formed was washed thoroughly

Table 1 PNA and oligonucleotide sequences used for hybridization detection

\begin{tabular}{ll}
\hline Nucleic acid probe & Sequence \\
\hline PNA Probe & $5^{\prime}$ NH $_{2}$-Cysteine-CGG TGG CGT GTT CTT TGT GCA ATA" C-terminal-3' \\
Thiol labeled DNA probe & $5^{\prime}$ SH-CGG TGG CGT GTT CTT TGT GCA ATA-3' \\
Complementary target & $3^{\prime}$-GCC ACC GCA CAA GAA ACA CGT TAT-5' \\
One base mismatch & $3^{\prime}$-GCC ACC GCA CAT GAA ACA CGT TAT-5' \\
Non-complementary & $3^{\prime}$-TTA GCA GGC AAT CGT TAG GAT TTC-5' \\
\hline
\end{tabular}


with autoclaved de-ionized water to remove any unbound probe and was stored at $4{ }^{\circ} \mathrm{C}$ when not in use.

\subsection{Characterization}

Both DNA/Au and PNA/Au bioelectrodes have been characterized by contact angle measurements by the Sessile drop method ${ }^{28}$ using a drop shape analyzer (DSA 100, DSA/V 1.9) from Kruss Gmbh Hamburg. Atomic force micrographs have been taken using a Veeco DICP2 atomic force microscope (loaded with SPM Lab analysis software). A phosphorus doped silicon tip was utilized for the scanning of the surface. The immobilization and hybridization experiments using SPR studies were recorded using an Autolab SPR, Eco Chemie (Netherlands), based on the traditional Kretschmann configuration. In SPR experiments, linearly p-polarized light from a laser $(670 \mathrm{~nm})$ is directed through a prism onto the gold electrode, and the intensity of reflected light as a function of time is measured over a range of 4000 millidegrees $\left(\mathrm{m}^{\circ}\right)$ at $25^{\circ} \mathrm{C}$. In the experiments, a goldcoated glass electrode is coupled with the plane face of the prism via an index matching fluid.

\subsection{Hybridization studies}

The hybridization studies have been carried out in triplicate sets using the SPR technique. In each SPR experiment, the SPR signal with the DNA/Au bioelectrode and PNA/Au bioelectrode is first recorded with de-ionized water for $120 \mathrm{~s}$ to obtain the baseline value, after which the solution of complementary sequence is added and is allowed to interact with the electrode for the next $800 \mathrm{~s}$ (association phase or nucleic acid hybridization). On completion of the association phase, the unused solution is discarded and the electrode is washed with de-ionized water (dissociation phase). After this, the SPR signal with de-ionized water is recorded and the change in the SPR angle is measured. This change in the SPR angle before and after the association phase corresponds to the amount of binding while keeping all other parameters constant. After the completion of the dissociation phase, the surface is fully regenerated by washing with solution $(5.0 \mathrm{mM} \mathrm{HCl})$ in the regeneration phase (nucleic acid denaturation) for $120 \mathrm{~s}$ (data not shown). To optimize the regeneration procedure, different concentrations of $\mathrm{HCl}$ and $\mathrm{NaOH}$ were tested. Among them, $\mathrm{HCl}$ shows a higher regeneration capacity at the optimized concentration of $5.0 \mathrm{mM}$. The single stranded probe can be regenerated by 2 min treatment with $5.0 \mathrm{mM} \mathrm{HCl}$ and is then ready for a new hybridization cycle (data not shown).

\subsection{Genomic DNA sample preparation}

The isolated genomic DNA of Mycobacterium tuberculosis was obtained from the Institute of Genomics and Integrated Biology (IGIB), New Delhi. The purity of DNA was calculated as about 1.0 using the equation:

$$
\frac{\text { Optical density (OD) at } 260 \mathrm{~nm}}{\text { Optical density (OD) at } 280 \mathrm{~nm}}
$$

The concentration of $M$. tuberculosis genomic DNA solution was estimated by UV-visible spectra (1.0 OD of ds DNA at $260 \mathrm{~nm}=50 \mu \mathrm{g} \mathrm{mL}-1$, was found to be $80.5 \mathrm{ng} \mathrm{mL}$.
The isolated genomic DNA of concentration $80.5 \mathrm{ng} \mathrm{mL}-1$ was subjected to sonication for 6 minutes at $120 \mathrm{~V}$ and $2 \mathrm{~A}$ (Ultrasonic Cleaner, Vibronics Pvt. Ltd., India) for denaturation of DNA. ${ }^{29,30}$ The obtained single stranded fragmented genomic DNA after sonication was tested in a similar way as that used for the standard sample.

\subsection{Results and discussion}

\subsection{Immobilization of DNA and PNA}

Fig. 1 shows SPR sensorgrams obtained for the immobilized thiolated DNA and PNA probe. It can be seen that the first phase of $120 \mathrm{~s}$ shows the baseline, after which solution of thiolated DNA or cysteine modified PNA is introduced for its immobilization for $8500 \mathrm{~s}$ onto the gold surface at $25^{\circ} \mathrm{C}$, followed by a washing step. The change in the SPR angle (or gradual increase in the angle with time) corresponds to the amount of binding of PNA/DNA at the surface. It has been found that there is a change of $205 \mathrm{~m}^{\circ}$ and $252 \mathrm{~m}^{\circ}$ for DNA and PNA binding, respectively. The larger change of SPR angle
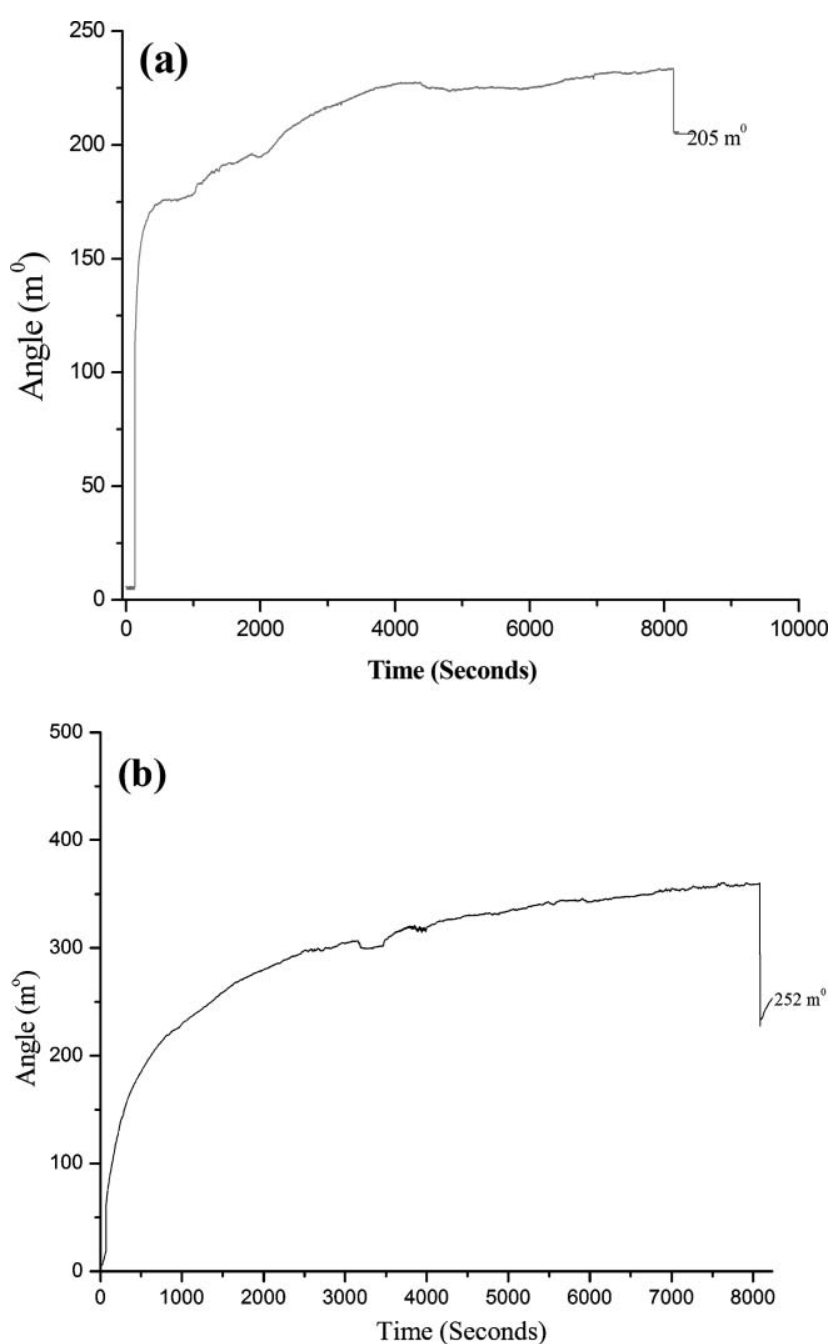

Fig. 1 SPR sensorgrams for covalent immobilization of (a) $5^{\prime}$-thiolated ssDNA and (b) cysteine modified PNA on gold (Au) film coated onto BK7 glass. 
for PNA indicates larger amount of PNA immobilized onto the gold surface.

\subsection{Contact angle measurements}

Contact angle studies have been carried out to characterize the immobilization of DNA and PNA on the gold surface. The change in the value of the contact angle values is related to the immobilization of thiolated DNA and PNA molecules. The contact angle value of the blank gold film (Fig. 2a) is found to be $76^{\circ}$, and decreases to $60^{\circ}$ after the immobilization of thiolated ssDNA (Fig. 2b). And the contact angle of the bare gold film changes to $54.57^{\circ}$ after PNA immobilization (Fig. 2c). The decrease in the contact angle values can be attributed to the presence of $\mathrm{NH}_{2}$ and $\mathrm{OH}$ groups in DNA and PNA, which helps to lower the contact angle values. ${ }^{31}$ The change in contact angle values after immobilization indicates successful binding of the nucleic acid (DNA/PNA) probes. The contact angle measurements were repeated a number of times and results were found to be similar in each case. It may be mentioned that we do not observe the approach of contact angle value towards $0^{\circ}$ after biomolecule immobilization. This may be assigned to the presence of the carbon chain skeleton and benzene ring structure of nitrogenous bases present in the DNA and PNA. We do not exactly understand at this stage the reason for such behavior.
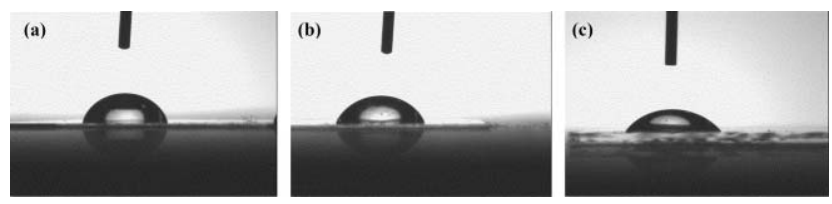

Fig. 2 Contact angle measurements of (a) blank gold $\left(76^{\circ}\right)$, (b) DNA/Au bioelectrode $\left(60^{\circ}\right)$ and (c) PNA/Au bioelectrode $\left(54.57^{\circ}\right)$

\subsection{Atomic force microscopic studies}

Fig. 3 shows atomic force micrographs (AFM) of the bare gold $(\mathrm{Au})$ electrode, $\mathrm{DNA} / \mathrm{Au}$ bioelectrode and $\mathrm{PNA} / \mathrm{Au}$ bioelectrode, respectively. The uniform distribution of granular structures (Fig. 3b and 3c) over smooth surface of the bare gold electrode (Fig. 3a) ${ }^{32}$ can be attributed to the immobilized DNA and PNA molecules, suggesting the formation of DNA and PNA SAM.

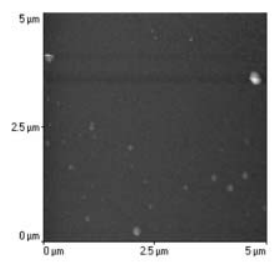

(a)

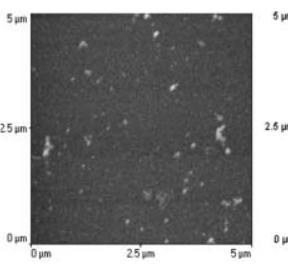

(b)

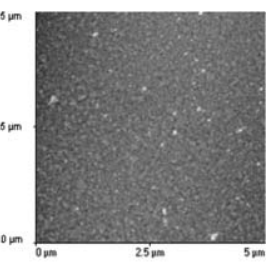

(c)
Fig. 3 AFM micrographs: (a) bare gold (Au) film, (b) DNA/Au bioelectrode and (c) PNA/Au bioelectrode.

The DNA/Au and PNA/Au bioelectrodes have been characterized using electrochemical techniques (cyclic voltammetry and electrochemical impedance measurement). The results indicate the successful immobilization and hybridization process (see ESI). $\dagger$

\subsection{Hybridization detection using surface plasmon resonance (SPR) studies}

Fig. 4 shows results of the SPR studies of DNA/Au and $\mathrm{PNA} / \mathrm{Au}$ bioelectrodes for detection of hybridization with the complementary $\left(7.3 \mathrm{ng} \mu \mathrm{L}^{-1}\right)$, one-base mismatch $\left(7.2 \mathrm{ng} \mu \mathrm{L}^{-1}\right)$, non-complementary sequences and sonicated genomic DNA (5-50 ng mL $\mathrm{mL}^{-1}$ ). In the SPR signal of DNA/Au bioelectrode (Fig. 4a), $203 \mathrm{~m}^{\circ}$ angle change is seen after hybridization with the complementary target $\left(7.3 \mathrm{ng} \mu \mathrm{L}^{-1}\right)$ indicating complete saturation of the electrode (Curve i). The change in angle of about $10.5 \mathrm{~m}^{\circ}$ is seen after hybridization with one-base mismatched sequence (Curve ii) indicating some non-specific binding. Negligible change is seen after hybridization with the non-complementary sequence (Curve iii). The DNA/Au bioelectrode has been utilized for various concentrations of complementary sequences and it has been found that it can detect up to $\sim 0.003 \mathrm{ng} \mu \mathrm{L}^{-1}$ or $3.0 \mathrm{ng} \mathrm{mL} \mathrm{L}^{-1}$ of complementary target.

Fig. 4b shows SPR curves obtained for the PNA/Au electrode after hybridization with the complementary, one-base mismatch and non-complementary sequences, respectively. The SPR angle change of $251 \mathrm{~m}^{\circ}$ is observed with the complementary sequence (7.3 ng $\mu \mathrm{L}^{-1}$ ) (Curve i), indicating total saturation (Fig. 4b). The one-base mismatch (Curve ii) and non-complementary sequence exhibit negligible binding (with an error of $\sim 2 \%$ ) with the PNA/Au bioelectrode, revealing absence of non-specific binding (Curve iii). The PNA/Au has been utilized for the estimation of various concentrations of the complementary sequence and

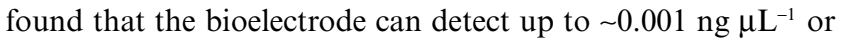
$1.0 \mathrm{ng} \mathrm{mL}{ }^{-1}$.

Attempts have been made to calculate the values of $k_{\mathrm{a}}$ (association constant) and $k_{\mathrm{d}}$ (dissociation constant) using both DNA/Au and PNA/Au bioelectrodes (Table 2). Compared to the DNA/Au bioelectrode, the PNA/Au bioelectrode shows higher association constant $k_{\mathrm{a}}\left(8.51 \times 10^{4} \mathrm{~m}^{-1} \mathrm{~s}^{-1}\right)$ for DNA hybridization detection of the complementary target. Furthermore, the PNA-Au bioelectrode does not exhibit any binding with the one-base mismatch target up to $\leq 15 \mathrm{ng} \mathrm{mL}^{-1}$, compared to the DNA/Au bioelectrode indicating considerable change in angle for concentrations more than $5 \mathrm{ng} \mathrm{mL}^{-1}$. Therefore, it can be concluded that the PNA/Au bioelectrode provides better specificity compared to DNA/Au as the bio-recognition element. Moreover, PNA/Au bioelectrode provides a better detection limit $\left(1.0 \mathrm{ng} \mathrm{mL}^{-1}\right)$ as compared to the DNA/Au bioelectrode (3.0 $\left.\mathrm{ng} \mathrm{mL}^{-1}\right)$. Further, the PNA/Au bioelectrode has been found to be reusable 8-9 times, compared to 5-6 times for the DNA/Au bioelectrode. The PNA/Au bioelectrode was tested at regular intervals of 5 days and has been found to be stable for about 30 days, compared to about 20 days for the $\mathrm{DNA} / \mathrm{Au}$ bioelectrode at $4{ }^{\circ} \mathrm{C}$. Keeping this in view, further experiments have been carried out using PNA/Au bioelectrodes to detect the presence of the complementary target in genomic DNA of $M$. tuberculosis.

The PNA/Au bioelectrode has been utilized to hybridize with the six-minute sonicated $M$. tuberculosis genomic DNA (Fig 4c). It is seen that the 6 minute sonication is sufficient to break the genomic DNA into an appropriate length to be hybridized with the PNA/Au electrode. ${ }^{29-30}$ The hybridization has been observed in a concentration range of $5-50 \mathrm{ng} \mathrm{mL}^{-1}$ of 

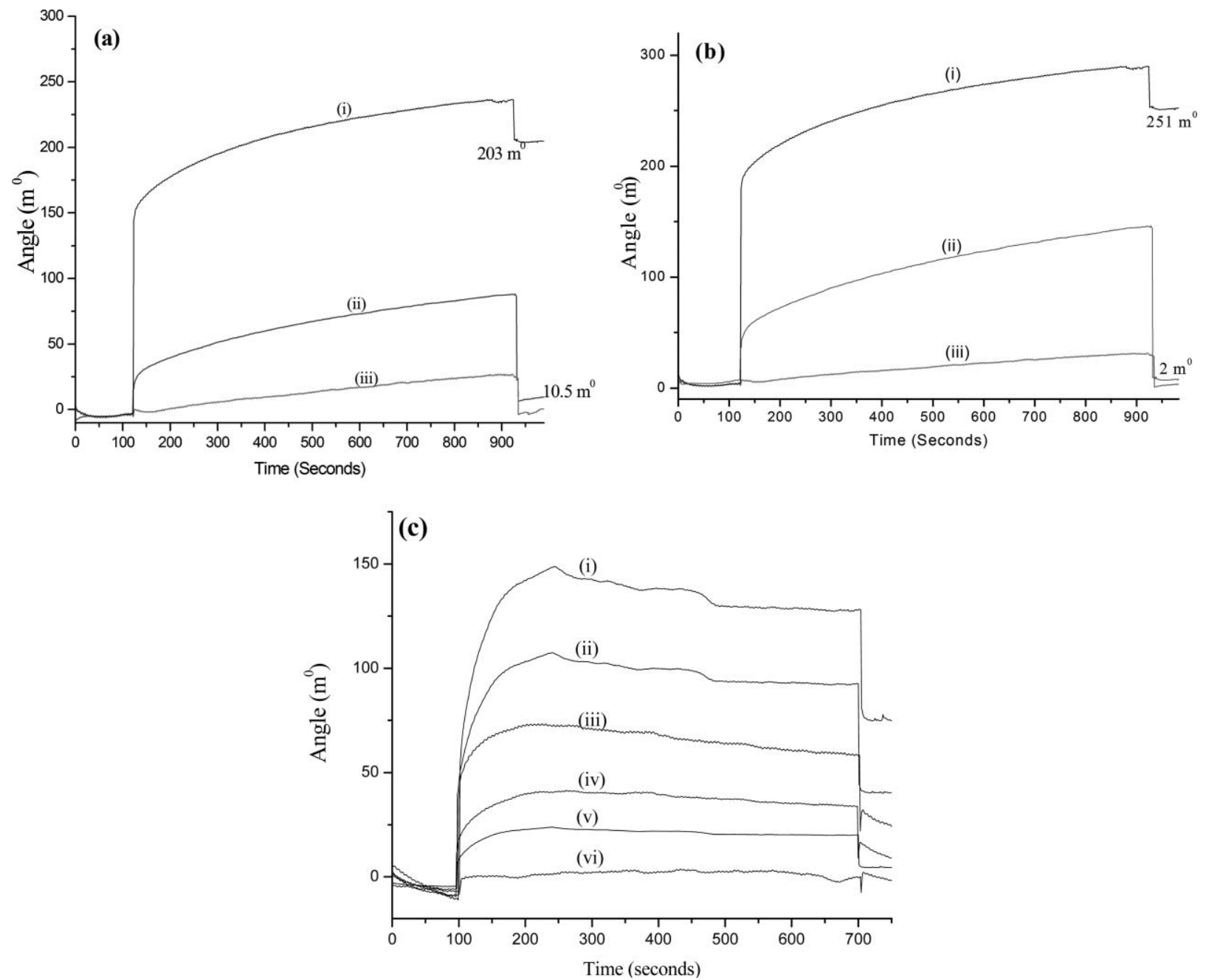

Fig. 4 SPR sensorgrams of (a) DNA/Au bioelectrodes; (b) PNA/Au bioelectrodes for hybridization detection with (i) complementary, (ii) one-base mismatch and (iii) non complementary targets using PNA/Au bioelectrode; and (c) PNA/Au bioelectrodes with genomic DNA concentrations of (i) $50.0 \mathrm{ng} \mathrm{mL} L^{-1}$, (ii) $30.0 \mathrm{ng} \mathrm{mL}^{-1}$, (iii) $20.0 \mathrm{ng} \mathrm{mL}^{-1}$, (iv) $15.0 \mathrm{ng} \mathrm{mL}^{-1}$, (v) $10.0 \mathrm{ng} \mathrm{mL}^{-1}$ and (vi) $5.0 \mathrm{ng} \mathrm{mL}^{-1}$.

Table 2 Association $\left(k_{\mathrm{a}}\right)$ and dissociation $\left(k_{\mathrm{d}}\right)$ constants of DNA/Au and PNA/Au bioelectrodes

\begin{tabular}{llcl}
\hline Electrodes & Kinetic rate constants & Complementary sequence & One-base mismatched sequence \\
\hline PNA/Au bioelectrode & $k_{\mathrm{a}} / \mathrm{m}^{-1} \mathrm{~s}^{-1}$ & $8.51 \times 10^{4}$ & - \\
& $k_{\mathrm{d}} / \mathrm{s}^{-1}$ & $3.6 \times 10^{-3}$ & - \\
DNA/Au bioelectrode & $k_{\mathrm{a}} / \mathrm{m}^{-1} \mathrm{~s}^{-1}$ & $2.1 \times 10^{4}$ & $2.1 \times 10^{3}$ \\
& $k_{\mathrm{d}} / \mathrm{s}^{-1}$ & $1.1 \times 10^{-3}$ & $1.7 \times 10^{-3}$ \\
\hline
\end{tabular}

the sonicated genomic DNA with an association time of $600 \mathrm{~s}$. A control experiment carried out with unsonicated DNA shows no binding at the surface. The detection limit for the genomic DNA has been found to be $10.0 \mathrm{ng} \mathrm{mL} \mathrm{m}^{-1}$.

\subsection{Conclusions}

It has been shown that thiolated DNA and PNA can be immobilized onto a gold surface via self-assembled monolayer formation. The PNA/Au bioelectrode shows an improved detection limit ( 3 times) and specificity for the complementary target using the surface plasmon resonance technique. It is revealed that PNA/Au bioelectrode can be used to detect complementary target sequence using genomic DNA of M. tuberculosis (10 ng $\mathrm{mL}^{-1}$ ) without the use PCR amplification and stringent washings. This SPR based PNA biosensor can be utilized efficiently for faster detection of the M. tuberculosis. Efforts are being made to improve the characteristics of PNA/Au bioelectrode and to directly detect the complementary sequence in $M$. tuberculosis in clinical samples.

\section{Acknowledgements}

We thank Dr Vikram Kumar, Director, NPL, New Delhi, India for his interest in this work. Nirmal Prabhaker is grateful to the University Grant Commission (UGC) India 
for the award of a Senior Research Fellowship (SRF). We thank Dr Y. Singh, Institute of Genomics and Integrative Biology (IGIB), CSIR, for samples of genomic DNA of $M$. tuberculosis. Financial support received under the DBT sponsored project (Grant/DBT/CSH/GIA/0212/2007) and Department of Science and Technology (DST), Govt of India (DST/TSG/ME/2007/06), India-Japan project (DST/INT/JAP/P-21/07).

\section{References}

1 K. Arora, S. Chand and B. D. Malhotra, Anal. Chim. Acta, 2006, 568, 259-274.

2 G. Ramsay, Nat. Biotechnol., 1998, 16, 40-44.

3 J. Wang, D. Xu, A. Kawde and R. Polsky, Anal. Chem., 2001, 73, $5576-5581$.

4 J. Wang, Nucleic Acids Res., 2000, 28, 3011-3016.

5 E. Giakoumaki, M. Minunni, S. Tombelli, I. E. Tothill, M. Mascini, P. Bogani and M. Buiatti, Biosens. Bioelectron., 2003, 19, 337-344.

6 E. Mariotti, M. Minunni and M. Mascini, Anal. Chim. Acta, 2002, 453, 165-172.

7 M. Steichen, Y. Decrem, E. Godfroid and C. Buess-Herman, Biosens. Bioelectron., 2007, 22, 2237-2243.

8 P. K. Wilson, T. Jiang, M. E. Minunni, A. P. F. Turner and M. Mascini, Biosens. Bioelectron., 2005, 20, 2310-2313.

9 P. E. Nielsen, M. Egholm, R. Berg and O. Buchardt, Science, 1991, 254, 1497-1500.

10 J. Wang, Biosens. Bioelectron., 1998, 13, 757-762.

11 B. Hyrup and P. E. Nielsen, Bioorg. Med. Chem., 1996, 4, 5-23.

12 M. Egholm, O. Buchardt, L. Christensen, C. Behrens, S. Freler, D. Driver, R. Berg, S. Kim, B. Nordern and P. E. Nielsen, Nature, 1993, 365, 566-568.

13 V. Demidov, V. Potaman, M. Frank-Kamenetskii, O. Buchardt, M. Egholm and P. E. Nielsen, Biochem. Pharmacol., 1994, 48, 13091313.

14 S. Sawata, E. Kai, K. Ikebukurno, T. Lida, T. Honda and I. Karube, Biosens. Bioelectron., 1999, 14, 397-404.
15 G. Evans, S. A. Charles, in 1st World Congress on Biosensors (Abstracts), Elsevier, Singapore, 1990, p. 223

16 U. Jonsson, L. Fagerstam, B. Ivarsson, B. Johnsson, H. Roos, I. Ronnberg, S. Sjolander, E. Stenburg, R. Stahlberg, C. Urbaniczky, H. Ostlin and M. Malmqvist, Biotechniques, 1991, 11, 620-627.

17 K. K. Jensen, H. Orum, P. E. Nielsen and B. Norden, Biochemistry, 1997, 36, 5072-5077.

18 M. Burgener, M. Sanger and U. Candrian, Bioconjugate Chem., 2000, 11, 749-754.

19 Y. Sato, K. Fujimoto and H. Kawaguchi, Colloids Surf., B, 2003, 27, 23-31.

20 T. Endo, K. Kerman, N. Nagatani, Y. Takamura and E. Tamiya, Anal. Chem., 2005, 77, 6976-6984.

21 K. Tawa, D. Yao and W. Knoll, Biosens. Bioelectron., 2005, 21, 322 329 .

22 D. Yao, J. Kim, F. Yu, P. E. Nielsen, E. K. Sinner and W. Knoll, Biophys. J., 2005, 88, 2745-2751.

23 D. Yao, F. Yu, J. Kim, J. Scholz, P. E. Nielsen, E. K. Sinner and W. Knoll, Nucleic Acids Res., 2004, 32, e177.

24 W. Knoll, H. Park, E. Sinner, D. Yao and F. Yu, Surf. Sci., 2004, 570, $30-42$.

25 J. H. Kim, J. A. Hong, M. Yoon, M. Y. Yoon, H. S. Jeong and H. J. Hwang, J. Biotechnol., 2002, 96, 213-221.

26 T. M. Herne and M. J. Tarlov, J. Am. Chem. Soc., 1997, 119, 89168920.

27 Y. Song, Y. Liu, M. Yang, B. Zhang and Z. Li, Appl. Surf. Sci., 2006, 252, 5693-5699.

28 A. Abdelghani, J. M. Chovelon, J. M. Krafft, N. J. Renault, A. Trouillet, C. Veillas, C. R. Triolli and H. Gagnaire, Thin Solid Films, 1996, 157, 284-285.

29 N. Prabhakar, K. Arora, H. Singh and B. D. Malhotra, J. Phys. Chem., 2008, 112, 4808-4816.

30 (a) K. Arora, N. Prabhakar, S. Chand and B. D. Malhotra, Anal. Chem., 2007, 79, 6152-6158; (b) K. Arora, N. Prabhakar, S. Chand and B. D. Malhotra, Anal. Chem., 2008, 80, 1833.

31 P. R. Solanki, S. K. Arya, Y. Nishimura, M. Iwamoto and B. D. Malhotra, Langmuir, 2007, 23, 7398-7403.

32 C. Briones, E. Mateo-Martí, C. G. Navarro, V. Parro, E. Rom'an and J. A. Martín-Gago, J. Mol. Catal. A: Chem., 2005, 228, 131136. 